\title{
Adhesion molecules before and after propylthiouracil in patients with subclinical hyperthyroidism
}

\author{
(D) Ferda Bilgir \\ (i) Oktay Bilgir ${ }^{2}$ \\ (D) Ozden Yildirim Akan² \\ (iD) Ismail Demir ${ }^{2}$
}

1. Katip Celebi University Ataturk Training and Research Hospital, Department of Allergy and Immunology, Izmir, Turkey. 2. Health Sciences University Bozyaka Training and Research Hospital, Department of Internal Medicine, Bozyaka, Izmir, Turkey.

\section{SUMMARY}

OBJECTIVE: This study aimed to investigate the effect of propylthiouracil treatment on adhesion molecules in patients with subclinical hyperthyroidism.

METHODS: In this study, a total of 168 patients diagnosed with subclinical hyperthyroidism were treated with propylthiouracil for one year. The levels of adhesion molecules, consisting of sICAM-1, sVCAM-1, and sE-Selectin, before and after the treatment were measured and compared. These results were compared with the levels of 148 healthy controls who received a placebo.

RESULTS: s/CAM-1 levels were significantly higher in subclinical hyperthyroidism patients than in healthy controls ( $\left.{ }^{*} p a=0.000\right)$. sICAM-1 levels were significantly decreased after the treatment $\left({ }^{* *} p b=0.000\right)$. Despite this decrease in patients with subclinical hyperthyroidism, it did not decrease to the level of the control group. sVCAM-1 did not change before and after propylthiouracil treatment. The level of sE-selectin was similar to that of the pretreatment control group, but it did not have statistical significance, although it increased after the treatment ( $\left.{ }^{* *} p b=0.004\right)$.

CONCLUSION: The sICAM level was significantly higher than the pretreatment values and decreased after the propylthiouracil treatment. However, further studies are needed to reduce the risk of atherosclerosis and cancer in patients with subclinical hyperthyroidism.

KEYWORDS: Hyperthyroidism. Propylthiouracil. E-Selectin. Intercellular adhesion molecule-1. Vascular cell adhesion molecule-1.

\section{INTRODUCTION}

Subclinical hyperthyroidism is the standard reference mean for free T3 and free T4 values and low or suppressed TSH. It is more common in women and increases with advanced age ${ }^{1}$. While clinical hyperthyroidism increases the risk of cardiovascular disease, heart rhythm, and fracture risk associated with osteoporosis, there are places where subclinical hyperthyroidism presents the same risks. Reports on cardiovascular risk indicate increased coronary artery disease $\mathrm{e}^{2}$. It increases the risk of atrial fibrillation and ischemic heart disease, and it has been more successful in elderly SHE patients receiving

DATE OF SUBMISSION: 16-Jan-2020

DATE OF ACCEPTANCE:26-Feb-2020

CORRESPONDING AUTHOR: Oktay Bilgir

Bozyaka Eğitim ve Araştırma Hastanesi - Saim Çıkrıkçı Caddesi Numara 59 - 35360 Karabağlar, - Izmir

Tel: +902322505050/5242; fax: +902322614444

E-mail: oktaybilgir@gmail.com 
l-thyroxine than in the normal population ${ }^{3}$. On the other hand, a five-population-based cohort study found a relative risk of coronary artery disease in patients with subclinical hyperthyroidism (SHE), 1.21 (95\% CI $=0.88-1.68)$ and $1.19(95 \% \mathrm{CI}=0.81-1.76)$ for cardiovascular mortality ${ }^{4}$.

The adhesion process and transendothelial migration of leukocytes are provided by cellular adhesion molecules. Cellular adhesion molecules (CAM) are expressed on the surface of the endothelium as a response to various inflammatory cytokines, such as interleukin-1, tumor necrosis factor- $\alpha$, and interferon- $\gamma^{5}$. Intracellular CAM-1 and vascular CAM-1 (VCAM-1) are two prototype members of the CAM immunoglobulin superfamily and play a primary role in focal leukocyte accumulation in the subendothelial area. An increase in the plasma levels of ICAM-1 and VCAM-1 can lead to inflammation, and there is also a risk of vascular occlusion in the coronary arteries ${ }^{6}$. E-Selectin, another member of the adhesion molecule family, allows the inclusion of inflammatory leukocytes, which are expressed on the surface of the endothelium.

Adhesion molecules play an important role in atherosclerosis and cancer ${ }^{6}$. TNF- $\alpha$ has an important role at the onset of inflammation, and a signaling pathway through TNF- $\alpha$, NF- $\beta$ is responsible for distant centers and the expression of co-ordination lines in the structure. Increased ICAM-1 expression may play an important role in the development of cancer? ${ }^{7}$.

Subclinical hyperthyroidism may trigger the development of cancer with molecule adhesion, inflammation, and atherosclerotic lesion formation. As a result, we planned to confirm adhesion molecule levels before and after propylthiouracil therapy in patients with subclinical hyperthyroidism.

\section{METHODS}

A total of 168 patients diagnosed with subclinical hyperthyroidism were given propylthiouracil treatment for one year. The levels of adhesion molecules before and after the treatment were compared. The cases were compared with 148 control patients receiving a placebo tablet 3 times per day. Subclinical hyperthyroidism was diagnosed in patients with normal free T3 and free T4 levels but below TSH levels. Patients received propylthiouracil $50 \mathrm{mg}$. The tablets were given 3 times per day. Placebo tablets were given to 148 normal healthy control groups three times a day for control purposes. The sICAM, sVCAM, and sE-Selectin levels of the subclinical hyperthyroid patients were measured before the treatment was started, and the same tests were repeated after 1 year of treatment.

All blood samples were collected under minimal tourniquet pressure. Blood samples were allowed to clot for 15 to 30 minutes and centrifuged at $1500 \mathrm{~g}$ for 10 minutes. The serum was then separated and stored at $-20^{\circ} \mathrm{C}$ until the analysis. Samples were thawed only once.

Serum sICAM-1, sVCAM-1, and sE-selectin concentrations were determined by enzyme-linked immunosorbent assay (ELISA) kit from Biosource (Bender MedSystems GmbH, Vienna Austria), according to the manufacturer's instructions. The sensitivity of the sICAM-1, sVCAM-1, and sE-selectin assays were 2.2 $\mathrm{ng} / \mathrm{mL}, 0.6 \mathrm{ng} / \mathrm{mL}$, and $0.3 \mathrm{ng} / \mathrm{mL}$ respectively. The intra-assay coefficients of variation (CV) for sICAM1, sVCAM-1, and sE-selectin were 4.1, 3.1, and $5.4 \%$, respectively, and the inter-assay coefficients of variation (CV) for them were 7.7, 5.2 and $6.0 \%$, respectively, according to the manufacturer.

\section{STATISTICAL ANALYSIS}

All the results were presented as mean \pm standard deviation (SD). The Kolmogorov-Smirnov normality test was used to determine the distribution pattern of the variables. To compare the normally distributed data, we used parametric independent-samples t-test (Student's t-test). Pre- and post-treatment sICAM-1, sVCAM-1, and sE-selectin values in patients with SHE were compared using the Wilcoxon Signed Ranks Test which is a nonparametric test.

The statistical analysis was carried out by using Statistical Package for the Social Science (SPSS), version 13.0 (SPSS Inc., Chicago, IL, US). A p-value of $<0.05$ was considered statistically significant.

\section{RESULTS}

The sICAM-1, sVCAM-1, and sE-Selectin levels of 168 SHE patients and 148 healthy controls were compared before and after the propylthiouracil treatment. In the SHE group, sICAM-1 levels were found to be significantly high in comparison with the healthy controls $\left({ }^{*} p^{a}=0.000\right)$. sICAM-1 levels were significantly decreased after treatment. Despite this decrease in patients with subclinical hyperthyroidism, it did not decrease to the level of the control group. $\left({ }^{* *}\right.$ 
$\left.\mathrm{p}^{\mathbf{b}}=0.000\right)$ (Table, Figure 1). No significant difference was found between healthy controls and patients with SHE in terms of sVCAM-1 levels $\left(p^{a}=0.632\right)$. Although sVCAM-1 levels were slightly increased after the treatment, no significant difference was found $\left(p^{\mathbf{b}}=0.089\right)$ (Table, Figure 2).

Although in patients with SHE sE-selectin levels were found to be slightly lower compared to those of healthy controls, that did not reach a statistically significant level $\left({ }^{*} \mathrm{p}^{\mathrm{a}}=0.293\right)$. sE-selectin levels did not show a significant change after the treatment $\left({ }^{* *} p^{\mathbf{b}}=0.114\right)$ (Table, Figure 3).

\section{DISCUSSION}

Atherosclerosis is a chronic process involving cellular and humoral responses. In atherogenesis, leukocytes are involved in the early period and this continues during plaque formation. sICAM-1 and sVCAM-1 coordinate leukocyte adhesion and transendothelial migration to generate this process ${ }^{8}$. Both sICAM-1 and sVCAM-1 are transmembrane glycoproteins linked to $\beta$-integrins in white blood cells. ICAM-1 endothelial cells are up-regulated with inflammatory cytokines in fibroblasts, epithelial cells, and multiple hemopoietic cells. In the absence of inflammatory conditions, ICAM-1 is expressed in small amounts on the cell surface, and the induction of this adhesion molecule may be important for regulating the intercellular interaction that constitutes the host immune response. VCAM-1 is specific to mononuclear cells and acts as a counter ligand for $\beta 1$ integrins in lymphocytes and monocytes. Although VCAM-1 expression modulates cytokines similar to ICAM-1, the distribution of VCAM-1 is limited to endothelial cells that are activated in lesion sites and are mostly observed in intimal neovascular structures. Despite the structural and functional similarities between ICAM-1 and VCAM-1, differences between tissue distributions, opposing receptor specificity, and response to hemodynamic forces play an important role in the

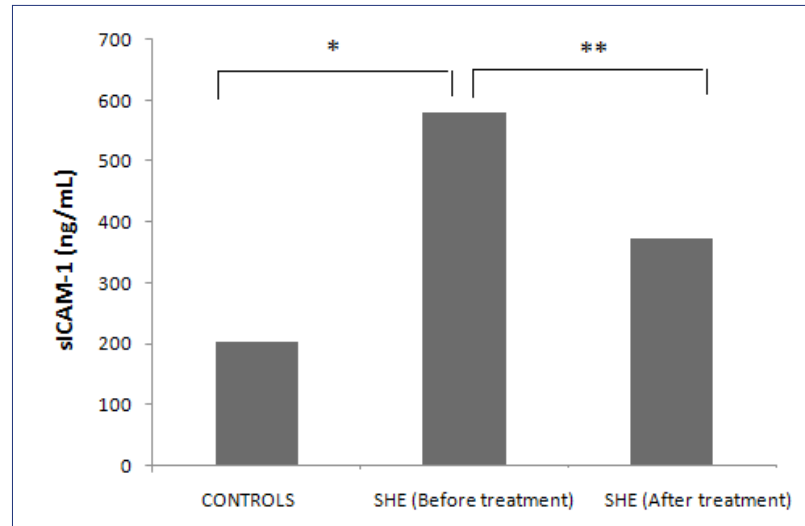

FIGURE 1. SICAM-1 LEVELS IN PATIENTS WITH SUBCLINICAL HYPERTHYROIDISM BEFORE AND AFTER PROPYLTHIOURACIL TREATMENT

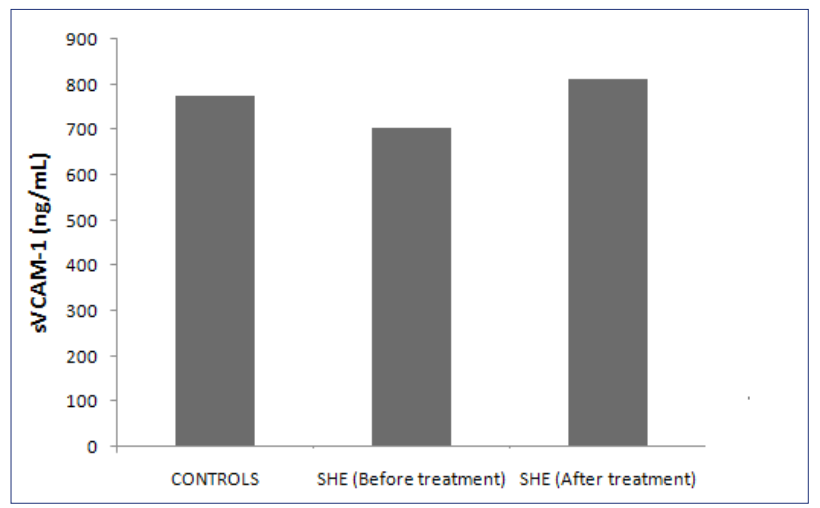

FIGURE 2. SVCAM-1 LEVELS IN PATIENTS WITH SUBCLINICAL HYPERTHYROIDISM BEFORE AND AFTER PROPYLTHIOURACIL TREATMENT

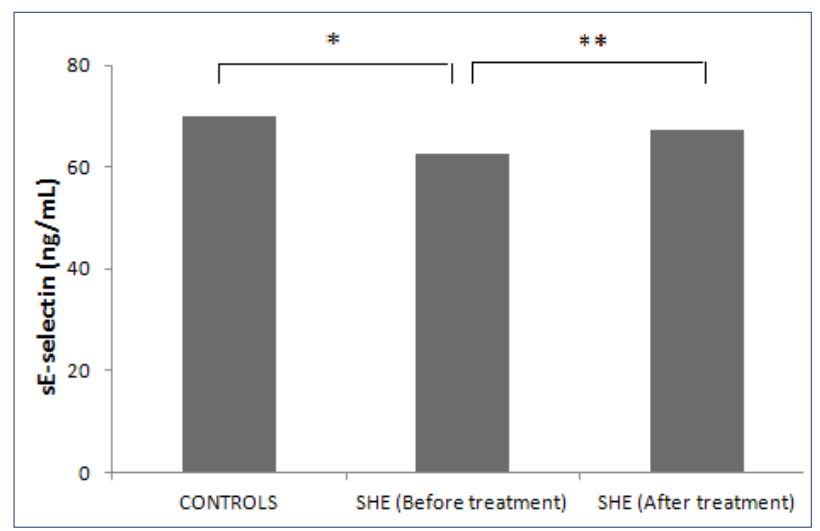

FIGURE 3. sE-SELECTIN LEVELS IN PATIENTS WITH SUBCLINICAL HYPERTHYROIDISM BEFORE AND AFTER PROPYLTHIOURACIL TREATMENT

TABLE. ADHESION MOLECULE LEVELS IN PATIENTS WITH SUBCLINICAL HYPERTHYROIDISM BEFORE AND AFTER PROPYLTHIOURACIL TREATMENT

\begin{tabular}{l|l|l|l|l|l} 
& $\begin{array}{l}\text { Controls } \\
(n=148)\end{array}$ & $\begin{array}{l}\text { SHE (Before treat- } \\
\text { ment) }(n=168)\end{array}$ & $\begin{array}{l}\text { SHE (After treatment) } \\
(n=168)\end{array}$ & $p^{\text {a } \text { values }}$ & $p^{\mathbf{b}}$ values \\
\hline sICAM-1 $(\mathrm{ng} / \mathrm{mL})^{\#}$ & $205.42 \pm 57.07$ & $581.80 \pm 137.12$ & $374.38 \pm 121.08$ & 0.000 & 0.000 \\
\hline sVCAM-1 $(\mathrm{ng} / \mathrm{mL})^{\#}$ & $773.06 \pm 817.41$ & $703.97 \pm 215.13$ & $811.78 \pm 506.77$ & 0.632 & 0.089 \\
\hline sE-selectin $(\mathrm{ng} / \mathrm{mL})^{*}$ & $70.08 \pm 28.96$ & $62.53 \pm 29.25$ & $67.17 \pm 29.95$ & 0.293 & 0.114 \\
\hline
\end{tabular}

$\mathrm{p}^{\mathbf{a}}$ values are calculated by statistically evaluating the control group and patients with SHE, and $p^{\mathbf{b}}$ values are calculated by statistically evaluating pre- and post-treatment values of patients with SHE. 
formation of systemic atherosclerosis ${ }^{9}$. Studies have shown that the increase in sICAM-1 level may be predictive of myocardial infarction and stroke $\mathrm{e}^{10,11}$ and the same assessment is not valid for sVCAM-1 ${ }^{12}$. Many researchers recognize that endothelial activation and inflammation are important precursors for the onset and progression of systemic atherosclerosis and play an independent role in the progression of peripheral atherosclerosis ${ }^{13}$.

Adhesion is important for cancer invasion between endothelial cells and cancer cells. ICAM-1 and E-selectin mediate this process. In general, the host's defense mechanisms of immune cells play an important role in the suppression of cancer metastases. It binds to ICAM-1 lymphocytes to suppress the functions of immune cells, i.e., they act as immunosuppressive agents $^{14,15}$. Some studies suggest that there is a relationship between the ICAM-1 molecule and cancer cells based on the increase in ICAM-1 expression, which is released by cancer cells and is related to the progression and metastasis of cancer ${ }^{16}$. In addition, many researchers have shown a significant association between forms of soluble adhesion molecules with gastric cancer, colorectal cancer, and breast cancer metastasis $^{17-19}$.

Selectins are adhesion molecules of the leucocytes with microvascular epithelium due to the lectin type interaction $^{20}$. The cytokines on the endothelial cell surface of E-selectin are activated there and adhere to the surface of the target molecules ${ }^{21}$. It has also been reported that cancer cells bind to the endothelial cell surface by E-selectin ${ }^{22}$. E-selectin is thought to be a metastasis tool with microvascular tumor cells ${ }^{23}$. Many studies support the hypothesis that the heterogeneous phase of metastases may provide metastatic distribution in circulating options in selective circulation $^{24,25}$

In this study, we observed that sICAM levels were higher in the subclinical hyperthyroid patients compared to the control group before treatment, and this value decreased after 1 year of treatment. On the other hand, the fact that the ICAM level did not decrease to the values in the control group shows that the risk of atherosclerosis and cancer is not completely eliminated. By varying the dose or duration of the propylthiouracil treatment or by using another therapeutic agent, sICAM levels can be reduced to acceptable levels and the risks can be eliminated. Further studies are needed to prevent cancer risks with atherosclerosis.

\section{Author's Contribution}

Ferda Bilgir: Conceptualization, validation; Oktay Bilgir: Methodology, project management; Ozden Yildirim Akan: Software, validation; Ismail Demir: Data curation, investigation.

\section{Funding}

None.

\section{Conflict of interest}

None.

\section{RESUMO}

ANTECEDENTES: O objetivo deste estudo foi investigar o efeito do tratamento com propiltiouracil nas moléculas de adesão em pacientes com hipertireoidismo subclínico.

MÉTODOS: Neste estudo, 168 pacientes diagnosticados com hipertireoidismo subclínico foram tratados com propiltiouracil por um ano. Os níveis de moléculas de adesão, especificamente s/CAM-1, sVCAM-1 e sE-Selectina, antes e após o tratamento foram medidos e comparados. Esses resultados foram comparados com os níveis de 148 indivíduos saudáveis no grupo de controle que receberam um placebo.

RESULTADOS: Os níveis de s/CAM-1 foram significativamente maiores em pacientes com hipertireoidismo subclínico do que nos controles saudáveis ( $\left.{ }^{*} \mathrm{pa}=0,000\right)$. Os níveis de s/CAM-1 diminuíram significativamente após o tratamento ( $\left.{ }^{*} p b=0,000\right)$. Apesar dessa diminuição em pacientes com hipertireoidismo subclínico, ela não diminuiu para o nível do grupo controle. O sVCAM-1 não se alterou antes e após o tratamento com propiltiouracil. O nível de sE-Selectina foi semelhante ao do grupo de controle pré-tratamento, mas não apresentou significância estatística, embora tenha aumentado após o tratamento $\left({ }^{* *} \mathrm{pb}=0,004\right)$.

CONCLUSÃO: O nível de SICAM foi significativamente superior aos valores pré-tratamento e diminuiu após o tratamento com propilciliouracil. No entanto, mais estudos são necessários para reduzir o risco de aterosclerose e câncer em pacientes com hipertireoidismo subclínico. 


\section{REFERENCES}

1. Vadiveloo T, Donnan PT, Cochrane L, Leese GP. The Thyroid Epidemiology, Audit, and Research Study (TEARS): the natural history of endogenous subclinical hyperthyroidism. J Clin Endocrinol Metab. 2011;96(1):E1-8.

2. Parle JV, Maisonneuve P, Sheppard MC, Boyle P, Franklyn JA. Prediction of all-cause and cardiovascular mortality in elderly people from one low serum thyrotropin result: a 10-year cohort study. Lancet. 2001;358(9285):861-5.

3. Bauer DC, Rodondi N, Stone KL, Hillier TA; Study of Osteoporotic Fractures Research Group: Universities of California (San Francisco), Pittsburgh, Minnesota (Minneapolis); Kaiser Permanente Center for Health Research, Portland. Thyroid hormone use, hyperthyroidism and mortality in older women. Am J Med. 2007;120(4):343-9.

4. Ochs N, Auer R, Bauer DC, Nanchen D, Gussekloo |, Cornuz |, et al. Meta-analysis: subclinical thyroid dysfunction and the risk for coronary heart disease and mortality. Ann Intern Med. 2008;148(11):832-45.

5. Dustin ML, Rothlein R, Bhan AK, Dinarello CA, Springer TA. Induction by IL 1 and interferon-gamma: tissue distribution, biochemistry, and function of a natural adherence molecule (ICAM-1). J Immunol. 1986;137(1):245-54.

6. Pober IS, Gimbrone MA Ir, Lapierre LA, Mendrick DL, Fiers W, Rothlein $\mathrm{R}$, et al. Overlapping patterns of activation of human endothelial cells by interleukin 1, tumor necrosis factor, and immune interferon. J Immunol. 1986;137(6):1893-6.

7. Blankenberg S, Rupprecht HJ, Bickel C, Peetz D, Hafner G, Tiret L, et al. Circulating cell adhesion molecules and death in patients with coronary artery disease. Circulation. 2001;104(12):1336-42.

8. Malik I, Danesh J, Whincup P, Bhatia V, Papacosta O, Walker M, et al. Soluble adhesion molecules and prediction of coronary heart disease: a prospective study and meta-analysis. Lancet. 2001;358(9286):971-6.

9. Galkina E, Ley K. Vascular adhesion molecules in atherosclerosis. Arterioscler Thromb Vasc Biol. 2007;27(11):2292-301.

10. Kobayashi H, Boelte KC, Lin PC. Endothelial cell adhesion molecules and cancer progression. Curr Med Chem. 2007;14(4):377-86.

11. Fraire AE, Woda BA, Savas L, Jiang Z. Intercellular adhesion molecules (ICAM-1, VCAM-1, and LFA-1) in adenocarcinoma of lung. Technical aspects. Methods Mol Med. 2003;74:243-9.

12. Price DT, Loscalzo J. Cellular adhesion molecules and atherogenesis. Am | Med. 1999;107(1):85-97.

13. O'Brien KD, McDonald TO, Chait A, Allen MD, Alpers CE. Neovascular expression of E-selectin, intercellular adhesion molecule-1, and vascular cell adhesion molecule-1 in human atherosclerosis and their relation to intimal leukocyte content. Circulation. 1996;93(4):672-82.

14. Lemos $\mid A$, Hennekens $\mathrm{CH}$, Ridker PM. Plasma concentration of soluble vascular cell adhesion molecule-1 and subsequent cardiovascular risk. J Am Coll Cardiol. 2000;36(2):423-6

15. Pradhan AD, Rifai N, Ridker PM. Soluble intercellular adhesion molecule-1, soluble vascular adhesion molecule-1, and the development of symptomatic peripheral arterial disease in men. Circulation. 2002;106(7):820-5.

16. Sánchez-Rovira P, limenez E, Carracedo I, Barneto IC, Ramirez R, Aranda E. Serum levels of intercellular adhesion molecule 1 (ICAM-1) in patients with colorectal cancer: inhibitory effect on cytotoxicity. Eur J Cancer. 1998;34(3):394-8

17. Koyama S, Ebihara T, Fukao K. Expression of intercellular adhesion molecule 1 (ICAM-1) during the development of invasion and/or metastasis of gastric carcinoma. J Cancer Res Clin Oncol. 1992;118(8):609-14.

18. Alexiou D, Karayiannakis AJ, Syrigos KN, Zbar A, Sekara E, Michail P, et al. Clinical significant of serum levels of $E$-selectin, intercellular adhesion molecule-1, and vascular adhesion molecule-1 in gastric cancer patients. Am J Gastroenterol. 2003;98(2):478-85.

19. O'Hanlon DM, Fitzsimons H, Lynch J, Tormey S, Malone C, Given HF. Soluble adhesion molecules (E-selectin, ICAM-1 and VCAM-1) in breast carcinoma. Eur | Cancer. 2002;38(17):2252-7.

20. Kang X, Wang F, Xie JD, Cao J, Xian PZ. Clinical evaluation of serum concentrations of intercellular adhesion molecule- 1 in patients with colorectal cancer. World J Gastroenterol. 2005;11(27):4250-3.

21. Bevilacqua MP, Nelson RM. Selectins. J Clin Invest. 1993;91(2):379-87.

22. Majuri ML, Mattila P, Renkonen R. Recombinant E-selectin-protein mediates tumor cell adhesion via sialyl-Le(a) and sialyl-Le(x). Biochem Biophys Res Commun. 1992;182(3):1376-82.

23. Ramphal JY, Hiroshige M, Lou B, Gaudino J), Hayashi M, Chen SM, et al. Ligand interactions with E-selectin. Identification of a new binding site for recognition of $\mathrm{N}$-acyl aromatic glucosamine substituents of sialyl Lewis $\mathrm{X}$. J Med Chem. 1996;39(7):1357-60.

24. Gout S, Tremblay PL, Huot J. Selectins and selectin ligands in extravasation of cancer cells and organ selectivity of metastasis. Clin Exp Metastasis. 2008;25(4):335-44.

25. Läubli H, Borsig L. Selectins promote tumor metastasis. Semin Cancer Biol. 2010;20(3):169-77. 